УДК 81'271

DOI: 10.33184/YVDK-2021-04-30.25

Ж.С. Джунусбекова (Шымкентский ун-т, РК, асп. БашГУ, г.Уфа)

\title{
О НЕКОТОРЫХ ОСОБЕННОСТЯХ ПРАЗДНИЧНОГО ЭТИКЕТА АМЕРИКАНЦЕВ В СИТУАЦИИ «НОВЫЙ ГОД»
}

В статье описаны некоторые особенности праздничного этикета американской лингвокультурной общности в ситуации празднования Нового года, рассмотрень правила поведения за новогодним столом, нормы внешнего вида участников новогоднего праздника и сочиальныий символизм новогодних подарков. При этом приведены в пример нормы поведения в современной Америке, описывающие ситуации, связанные с технологизацией жизни в XXI веке.

Ключевые слова: США, этикет, Новый год, праздничный этикет, манеры, нормы поведения.

The article describes some of the features of the festive etiquette of the American linguocultural community in the situation of celebrating the New Year, considers the rules of behavior at the New Year's table, the norms of the appearance of participants in the New Year's holiday and the social symbolism of New Year's gifts. At the same time, the norms of behavior in modern America are given as an example, describing situations associated with the technologization of life in the 21st century.

Keywords: USA, etiquette, New Year, holiday etiquette, manners, norms of behavior.

Теория социальной нормы характеризует вежливое поведение через соблюдение общепринятых социальных норм. Согласно данной теории, действия считаются вежливыми, если они соответствуют этикетным нормам той или иной лингвокультурной общности. Напротив, не соответствующие нормам действия расцениваются как невежливые, т.е. грубые [Газизов 2017: 15]. 
Правила и нормы поведения на праздничном мероприятии предусматривают соблюдение такого типа коммуникативного этикета, как праздничного. Этикет - это система ориентации в области социально-культурных координат, сформированная сквозь призму исторических, социальных и национальных особенностей [Басманова 2006: 131].

Правила поведения на новогоднем мероприятии в Америке отличаются в зависимости от места проведения вечеринки: в домашней атмосфере, на корпоративном банкете или светском приёме [Романова 2014: 186].

Незнание элементарных правил этикета способно привести к конфликтам, недоразумениям или срыву договорных отношений между компаниями. С учетом того, что в Америке принято решать вопросы, связанные с деловыми отношениями, даже во время Новогоднего корпоратива соблюдение норм поведения предельно актуально. Рассмотрим специфику праздничного этикета во время празднования Нового года в США.

Как известно, праздничный этикет американцев впитал в себя этническое многообразие европейских национальностей, поскольку США были созданы иммигрантами из разных уголков мира [Малюга 2008: 164]. Тем не менее, «правила этикета, принятые в США, имеют множество несовпадений с традициями общегражданского этикета европейских стран и России» [Басманова 2006: 131].

В XXI веке канун Нового года и его первый день имеют для многих американцев религиозное значение: в христианских церквях проводится «Новогодняя всенощная» ("Watch Night" services) - традиция, связанная с Провозглашением эмансипации (от 01.01.1863 г.) - празднованием свободы афроамериканцев. Для католиков 01 января, или «Торжество Марии» ("The Solemnity of Mary"), является Святым Днем Обязательства, когда все должны присутствовать на мессе в День Нового года [Murtaugh 2020].

Прежде чем приглашать гостей, организаторы праздника должны заранее уведомить об этом соседей и извиниться перед ними за потенциальные неудобства [Betts-Johnson 2021].

При приглашении на любой праздник, в том числе, на Новый год, в первую очередь рекомендовано соблюдение так 
называемого протокола RSVP. RSVP - это запрос ответа от приглашённого человека. Изначально данная аббревиатура использовалась французами и звучала следующим образом: "Répondez s'il vous plaît" (фр., букв. «Пожалуйста, ответьте») [Capetta 2017; Breindel 2019; Youst 2021].

Важно подчеркнуть, что в США RSVP не означает, что следует отвечать только в том случае, если вы приедете ('respond only if you are coming"). Необходимо заранее уведомить в письменной или устной форме, пойдет ли человек на празднование или нет в течение $24-\mathrm{x}-48$-ми часов. Это позволит хозяину / организатору своевременно подготовить необходимое количество еды, напитков и подарков на определенное количество гостей [Capetta 2017; Breindel 2019; Youst 2021]. Очень важно дать точный ответ: "Yes" («Да»), либо "No" («Hет»). Сказать "No" не считается невежливым, а вот согласиться прийти и не выполнить обещание - большое этикетное нарушение [United States (American) dining etiquette]. Дело в том, что лицо, отправляющее приглашение, является хозяином и несет ответственность за оплату счетов или других расходов, связанных с мероприятием [Schweitzer 2021].

Американцы ожидают, что гости придут точно в оговоренное время. Если приглашенный опаздывает, следует предупредить их об этом. Чрезмерное запоздание свидетельствует о неуважении к организатору мероприятия и гостям, а небольшая задержка сочтется за безалаберное отношение к приглашению опоздавшего расценят как ненадежного человека, с которым не стоит иметь серьезных дел, в том числе, в бизнесе. Рекомендовано приезжать за 15-20 минут до начала мероприятия, а уезжать - за 30 минут до его окончания [Schweitzer 2021].

При получении подарка или приглашения на праздник, американский этикет обязывает отправить рукописное или электронное благодарственное письмо с выражением признательности. При этом более импонирует рукописная благодарность, как более редкое и осязаемое, соответственно, более ценное средство коммуникации.

Новый год американцы отмечают либо в ресторане, либо в домашней обстановке с друзьями и / или родственниками. В ресторане правила этикета предписывают быть вежливым со своим официантом, что включает простое приветствие, например, 
"hi" или "hello"; также официант может завязать лёгкую беседу, поинтересовавшись, как прошёл день у заказчика или чем он сегодня занимался, на что будет корректным ответить: "good" или кратко рассказать о себе.

Поддерживать разговор во время еды - задача хозяина или организатора праздника, а гости должны вежливо вносить свой вклад в беседу, проявляя заинтересованность к обсуждаемым темам [Schweitzer 2021].

Разговор в компании должен быть легким и оптимистически настроенным: люди задают короткие вопросы и получают на них такие же ответы - американцы чувствуют себя неуютно, если кто-то из компании долго говорит [Murray 1999], т.е. доминирует в разговоре. В то же время считается неприличным, если гость молчит и ни с кем не общается. При этом любое знакомство может оказаться полезным (B. Tsai, founder of etiquette training program Beyond Etiquette), объясняется это склонностью американцев к прагматизму, а именно, «беседа с партнёром должна (может - прим. автора) принести какую-то пользу» [Багана 2017: 79].

Если адресату не нравится вопрос, который ему задают, рекомендовано просто улыбнуться и сказать: "In my country, that would be a strange question" «B моей стране это был бы странный вопрос» [Murray 1999].

Самая популярная новогодняя традиция - это обсуждение и принятие решений, а также постановка целей на предстоящий Новый год [Murtaugh 2020].

При праздновании Нового года в организации, где американец работает, считается релевантным общаться не с друзьями, а стараться завязать разговор с руководством, генеральным директором, коллегами более высшего звена, клиентами, лицами из других отделов - теми людьми, с которыми разговор может оказаться полезным [Малюга 2008: 127; Багана 2017: 79; Schweitzer 2021]. Например, при общении с генеральным директором, если практически нет возможности с ним поговорить в рабочее время, следует сначала представиться, назвать отдел, в котором адресант работает и пожать начальнику руку, далее обсудить какие-то вопросы - такие взаимоотношения могут положительно повлиять на дальнейший карьерный рост [Schweitzer 2021]. 
Начинать разговор можно с таких тем, как «путешествие», «домашние животные», «книги» или «фильмы», следует избегать сплетен, а также таких тем, как «религия», «политика» и «секс» (Sh. Schweitzer, D. Gottsman). При беседе на неофициальном приеме и вне корпоративного праздника, не стоит говорить о бизнесе [Gottsman 2017; Capetta 2017; Schweitzer 2021].

В домашней обстановке в течение всей беседы также надлежит сохранять оптимистический и лёгкий настрой. Одна из ролей хозяйки - задавать гостям открытые вопросы об их жизни. Например, интересоваться их родом деятельности, хобби, книгами, которые они прочитали, фильмами, которые они смотрели, или телешоу, которые они предпочитают. «Люди любят говорить о путешествиях, поэтому спрашивайте о планах на предстоящие поездки, об их впечатлениях за прошедшее лето или о том, куда они хотели бы поехать в наступающем году», рекомендует Sh. Schweitzer [Capetta 20017; Schweitzer 2021].

Если кто-то из гостей начинает обсуждать неприемлемую для всех тему, из-за чего гости нервничают или чувствуют себя дискомфортно, то задача хозяйки: вмешаться и направить всё в позитивное русло, например, сказав: "This is clearly a hot topic, so I'm going to suggest we table it and focus on things that are positive" («Это явно горячая тема, поэтому я предлагаю оставить ее и сосредоточиться на более позитивных вещах»). Если в неприятном разговоре принимает участие гость, а хозяина нет поблизости, рекомендовано или промолчать, или извиниться и пойти, к примеру, в уборную [Schweitzer 2021].

Первый тост принадлежит хозяину или хозяйке дома [Schweitzer 2021; Breindel 2019]. Далее тост произносит почетный гость, в котором выражает благодарность хозяевам за приглашение на праздник. Неформальные и официальные приемы предусматривают поднятие бокала и произнесение слова "Cheers" («Ваше здоровье») [United States (American) dining etiquette].

Тосты, предлагаемые другими гостями, произносятся во время десерта по отдельности либо совместно (поднятие бокалов и одновременное произнесение слова "Cheers").

Анализируя невербальное коммуникативное поведение американцев, в первую очередь следует упомянуть улыбку, которая, согласно исследованиям И.А. Стерина и М.А. Токаревой, 
«является непременной частью разговора» [Токарева 2007: 24] даже в тех ситуациях, когда люди встречаются взглядом с чужими людьми в транспорте, на улицах города или в других местах, не говоря о праздниках в кругу семьи и близких.

«Приветливость и вежливость американцев - это соблюдение этикета, политкорректность» [Багана 2017: 73]. В противном случае они «чувствуют себя неуютно, им кажется, что они сделали что-то не так» [Токарева 2007:22] или у неулыбающегося коммуниканта случилась какая-то трагедия, несчастье. Как пишет Ж. Багана, «Американец обязан верить в счастье: в Конституции США это четко отмечено: «жизнь, свобода, стремление к счастью», при этом оно расценивается не как общее благо, а как личное дело каждого. «Быть несчастным неестественно, неприлично, ненормально» [Багана 2017: 80], подчёркивает специалист по этикету.

При разговоре обязателен зрительный контакт. Он демонстрирует, что и адресант, и адресат обращают внимание на говорящего или на своего собеседника.

Если человек, пришедший на праздник, видит некоторых гостей впервые, не рекомендовано обнимать или целовать их как правило, в США избегают физического контакта при первой встрече [Proper American Etiquette in the United States], однако, следует улыбнуться и назвать своё имя.

Рассматривая вопрос о застолье и диетических ограничениях, отметим, что при получении приглашения в США принято обращать внимание на особые диетические потребности. Хозяин должен заранее спросить о пищевой аллергии или об особом «гастрономическом» отношении гостей к каким-либо продуктам (речь идет о соблюдении кошерной, халяльной, безглютеновой, безсахарной или / и безмолочной и прочих диетах). Гость должен в течение 24 часов ответить на приглашение, указав свои любые диетические ограничения [Schweitzer 2021].

При приглашении на празднование Нового года в дом / квартиру, а не в ресторан, гостям также рекомендовано приносить c собой лёгкие закуски, однако, следует предварительно осведомиться о наличествующих аллергиях или пищевых ограничениях хозяев и гостей (Sh. Schweitzer) [Breindel 2019; Schweitzer 2021]. Также будет вежливым принести с собой 
бутылку спиртного: "When you are a guest at a New Year's Eve party, bring a new, unopened bottle of wine", [Breindel 2019; Youst 2021] («Придя в гости на Новогоднюю вечеринку, принесите новую, неоткрытую бутылку вина»).

При праздновании Нового года в домашней обстановке гостям не рекомендовано начинать есть, пока не начнут есть хозяева. Сначала следует предложить помощь окружающим (достать что-то с тарелки или налить напиток), а затем положить угощение себе [Murray 1999; United States (American) dining etiquette].

Если празднование Нового года проходит в ресторане, невежливым считается заказывать самое дорогое блюдо из меню - этим заказчик проявляет небрежность в отношении того, кто платит за заказ (даже если ужин оплачивается компанией), либо снобизм (будто бы заказчик выставляет напоказ свой достаток, ущемляя друзей, т.е. принижая их самодостаточность, подчеркивая данным поступком, что они зарабатывают меньше) [Proper American Etiquette in the United States].

Не следует разговаривать по мобильному телефону или осуществлять переписку в мессенджерах в присутствии гостей это считается грубым и заставляет думать окружающих, что человек к ним равнодушен. Разговоры по телефону или переписка в чатах вызывает у присутствующих раздражение. Если гость нарушает этикет и постоянно возвращается к гаджету, хозяйка может сказать "You can say, 'We're looking forward to a cell-free dinner". «Mbl с нетерпением ждем ужина без сотовой связи» или "We would like everyone to silence their phone for this meal" [Capetta 2017; Gottsman 2017] «Mы бы хотели, чтобы все отключили свой телефон во время обеда». Телефон следует убрать со стола в сумку или карман, так как это не предмет посуды и не столовый прибор [Там же].

Если предлагают вторую порцию еды, не стоит стесняться брать то, что нравится - американцы любят много есть. При этом в США обычно едят быстрее, чем люди из других стран, так как смысл Новогоднего ужина в том, чтобы удовлетворить аппетит, а не общаться, наслаждаясь едой [Murray 1999; United States (American) dining etiquette], при этом ценится в первую очередь удобство, поэтому, как правило, не тратится много времени на готовку изысканных блюд, а предпочитается еда быстрого 
приготовления, «еда на вынос», полуфабрикаты или празднование Нового года в ресторане.

В приглашении зачастую указано: ужин запланирован в виде фуршета, шведского стола или с сидячими местами. Если гости будут есть стоя, эксперты по культуре и этикету S. Wexler и Sh. Schweitzer рекомендуют плотно поесть перед тем, как отправиться на мероприятие, в противном случае минимализм в угощениях (количестве и размерах закусок) и большое количество спиртного быстро введут гостя в состояние алкогольного опьянения [Wexler 2021], а также считается неприличным проводить основную часть времени возле стола с угощениями, потребляя много закусок [Schweitzer 2021].

Чаще всего Новогодний вечер предполагает угощение по системе «шведский стол» или фуршет [United States (American) dining etiquette], поэтому держать бокал или тарелку рекомендовано в левой руке, чтобы правая рука оставалась свободной для рукопожатий с вновь прибывшими или уходящими гостями [Breindel 2019; Schweitzer 2021].

Не следует пребывать на мероприятие в состоянии алкогольного опьянения или с запахом, свидетельствующем о том, что человек уже потреблял спиртное [Youst 2021], - отмечает J. Youst.

Ввиду того, что некоторые гости могут воздерживаться от алкоголя в силу личных убеждений или по индивидуальным причинам, невежливо заставлять или уговаривать кого-то потреблять спиртные напитки. Данное правило обусловлено двумя факторами: (1) важный социальный аспект каждого американца - это «демонстративный оптимизм и недопустимость жалоб (нельзя признаваться в своих неудачах и выглядеть унылым, ибо это грозит потерей лица)» [Багана 2017: 79], соответственно, человек не станет распространяться о своих проблемах со здоровьем или о других причинах, побудивших не потреблять алкоголь, также считается неприличным настаивать «жаловаться» на свою личную жизнь и / или оправдываться (просить ответить, по какой причине человек не пьет спиртное); (2) американец ценит превыше всего свои личное пространство и независимость. 
Празднование Нового года занимает несколько часов, но не рекомендовано задерживаться слишком долго. В Америке существует несколько признаков того, что пора уходить:

1. Хозяин начинает уборку.

2. Другие гости начинают расходиться и количество людей уменьшается.

3. Ведущий говорит, что мероприятие закончилось, или благодарит всех за участие [Proper American Etiquette in the United States].

Перед отъездом следует поблагодарить хозяев или организаторов праздника за проведенное мероприятие. В ситуации, если это был корпоратив, следует поблагодарить руководство [Schweitzer 2021].

Гостю необходимо заранее позаботиться о транспорте, на котором он вернется домой после торжества (с учётом того, что в Новогоднюю ночь в Америке общественный транспорт практически не ходит), например, вызвать такси или заранее договориться с кем-то из гостей возвращаться вместе на одном автомобиле. Считается невежливым просить хозяина отвозить гостя домой и, тем более, неприлично проситься остаться у него ночевать дома [Tsai 2021; Breindel 2019].

При этом хозяевам / организаторам важно позаботиться о том, чтобы слишком опьяненный гость благополучно вернулся домой после праздника [Breindel 2019; Youst 2021], для этого рекомендовано, например, вызвать ему такси.

Уйти с мероприятия следует с тем человеком, с которым гость пришел, т.к., согласно американской традиции: "The first hug of the new year should be reserved for the one you came with" (J. Youst) [Youst 2021] («Первые объятия в Новом году принадлежат тому, с кем Вы пришли»).

Если гость или хозяин хотят разместить фотографии с Нового года в социальных сетях, где они находятся в компании друзей, они обязаны спросить на это разрешение у каждого присутствующего на снимке. В противном случае ставится под угрозу репутация человека, вплоть до того, что его могут уволить, если компания (где он работает) сочтет данный снимок угрозой для собственного имиджа [Breindel 2019; Youst 2021].

Правильная одежда зависит от региона страны, компании человека, в которой он работает, его положения в ней и в отрасли 
[Murray 1999], при этом у каждого праздника свой дресс-код, который часто может быть тематическим.

Следует одеваться так, как указанно в приглашении, например, если рекомендовано надеть чёрный галстук, необходимо обязательно это выполнить. Если в приглашении нет определенного дресс-кода, следует посоветоваться о выборе костюма с хозяином [Breindel 2019; Youst 2021].

Когда празднование Нового года проводится организацией, в которой человек работает, на предмет дресс-кода (если это не напечатано на пригласительном билете) следует советоваться в отделе кадров или у коллег, с которым сотрудник находится в дружественных отношениях. На «офисный» Новый год рекомендовано надеть скромную одежду, которая поддерживает профессиональную репутацию, так как подобного плана мероприятие среди американцев считается «продолжением рабочего дня». Также надлежит избегать «коротких юбок, обтягивающей одежды или неподходящих уродливых рождественских свитеров» [Schweitzer 2021].

Не следует одеваться шикарно или чрезмерно оголяться, в то же время необходимо следовать моде и быть сдержанным в своем наряде [Breindel 2019; Youst 2021].

При встрече Нового года в домашней атмосфере, входя в дом, гости обувь не снимают. Если обувь мокрая или в снегу, рекомендовано взять с собой сменную пару и переобуться (S. Wexler) [Breindel 2019; Wexler 2021].

Подарки. Подарок сквозь призму социального символизма можно интерпретировать как средство невербальной коммуникации, семиотическая функция которого заключается во внешнем проявлении человеческих взаимоотношений. В Америке подарки выбираются согласно концепции "Giving people what they want" [Fox 2019] («Дать людям то, что они хотят»).

Первое правило этикета гласит, что никогда нельзя приходить на праздник без подарка - посредством сувенира выражается признательность хозяину или хозяйке за приглашение (Sh. Schweitzer) [Capetta 2017]. Когда планируется большое количество гостей, а не празднование Нового года в узком семейном кругу, в качестве подарка может послужить небольшая безделушка, украшение для ёлки или, например, футболка с принтом-фотографией хозяев [Breindel 2019; Schweitzer 2021]. 
Согласно этикету, необязательно дарить подарок руководителю, но, как отмечает D. Gottsman, в качестве признательности или из импонирующих соображений всё равно хочется преподнести какой-то презент. Для этого рекомендовано угостить выпечкой, независимо от того, исходит инициатива от сотрудника или от работодателя [Gottsman 2017; Capetta 2017].

Как отмечает E. Swann, «слишком часто мы выбираем подарки, основываясь на том, что, по нашему мнению, человек должен иметь, на самом деле вкладывая в это свои мысли - свои симпатии и свои увлечения». В опросе 1000 американцев, проведенном Mint.com в 2019 г., 61\% заявил, что предпочитает деньги или подарочную карту. «Менталитет американцев прагматичен» [Малюга 2008: 127], поэтому деньги в США считаются наиболее релевантным подарком: "Cash is king" [Fox 2019] («Король подарков - это наличные»), заявляют американские эксперты по этикету Myka Meier и Elaine Swann.

Что касается чаевых, которым в Америке также уделяется большое внимание, следует отметить, что, согласно мнению D. Gottsman, в США нет определенной суммы, предусмотренной именно для Новогодних праздников. Специалист по этикету предлагает примерные варианты «новогодних» чаевых, равных по сумме следующим единицам оплаты труда (если дарителю позволяет заработок): (а) в сфере услуг сумма чаевых равна сумме за один визит к любому из специалистов (например, парикмахер, мастер по маникюру, грумер и пр.); (б) няне можно дать чаевые, равные по сумме за одну вечернюю смену; (в) воспитателю детского сада - за одну недельную или месячную оплату труда, нянечке (помощнице воспитателя) - подарочный сертификат на 25-50\$; (г) работнику по выгулу собак - сумму, равную одной недельной оплате или одному-двум сменам по уходу за домашним питомцем и пр. [Capetta 2017; Gottsman 2017].

Однако в Америке не всем разрешено принимать денежные подарки. Деловая этика не позволяет давать чаевые даже в Новый год любому государственному служащему, а также тем, кто работает в финансовой, медицинской и юридической отраслях, - уточняет Sh. Schweitzer. Напомним, что сотрудники таких структур могут принимать в качестве подарка выпечку. В крайнем случае, можно спросить про политику дарения подарков конкретной фирмы у самого сотрудника [Capetta 2017]. 
Если кто-то из друзей, родственников, сослуживцев или соседей вручает неожиданный новогодний подарок, рекомендовано не зацикливаться на том, что у адресата нет ответного подарка. Вместо этого необходимо с благодарственной улыбкой принять презент, посмотреть этому человеку в глаза и сказать: "Thank you so much - how thoughtful!" «Большое вам спасибо - очень приятно!» (D. Gottsman). Совершенно нормально, если адресат решит преподнести ответный подарок в другой день или в знак признательности угостить обедом, например, после праздников. Но не стоит говорить: "Oh, I have something for you, too, but I haven't wrapped it yet,' because it just comes across as an excuse" («У меня тоже есть кое-что для тебя, но я еще не упаковал это»), что может быть расценено как оправдание, которое умаляет достоинство американца, - отмечает D. Gottsman [Gottsman 2017; Capetta 2017].

По окончании новогоднего вечера ввиду того, что хозяин дома или организатор потратил немало усилий (и расходов) на организацию праздника, следует написать персонализированное письмо (в письменной или электронной форме) со словами благодарности о проведенном мероприятии.

На сегодняшний день американцы - это уже отдельная нация, отличная от европейцев по ментальности, влияющей на нормы и правила поведения в социуме. Однако глобализация культур вновь стирает границы между этикетными формами, так как дружественно настроенные друг к другу народы и страны стараются впитать в себя лучшие традиции и манеры поведения в обществе.

\section{ЛИТЕРАТУРА}

1.Багана Ж. Основы теории межкультурной коммуникации [Текст]: учебнюе пособие / Ж. Багана, Н.И. Дзенс, Ю.Н. Мельникова. - 3-е изд, стер. - Москва: ФЛИНТА, 2017. $-307 \mathrm{c}$.

2.Басманова Э.Б. Гостевой этикет, или Домашний прием на высшем уровне / Эля Басманова.-Москва: Олимп [и др.],2006.-245с.

3.Газизов Р.А. Коммуникапивный этикет в аспекте линпвистической вежливости: монография-Уфа: РИЦБашГУ,2017.-196с.

4.Малюга Е.Н. Функциональная прагматика межкультурной деловой коммуникации [Текст]/Е.Н. Малюга. - Изд. 2-е, доп.-Москва:URSS, 2008. -313 c.

5.Романова А.Г. Современный этикет [Электронный ресурс]: болышая энциклопедия / [А. Г. Романова,Е. В. Сухарева]. -2-еизд, доп.-Москва:Эксмо, 2014. -240 с. 
6. Токарева М.А. Феномен улыбки в русской, английской и американской культуре: диссертация ... кандидата культурологии: 24.00.01.-Москва, 2007.-195 с.

7.Betts-Johnson, M. International Protocol, Business Etiquette \& Diplomacy. URL: hitps://mbjprotocol.com/. Date: 04.03.2021.

8. Breindel, A. The Best and Worst New Year's Eve Party Etiquette. Best Life. Dec. 11. 2019. URL: hitps://bestlifeonline.com/new-years-eve-party-etiquette/.Date: 03.03.2021.

9. Capetta, A. 9 Unspoken Etiquette Rules Everyone Should Follow. Country Living. NOV 21, 2017. URL: hitps://www.countryliving.com/life/news/a45739/holiday-etiquette-rules/. Date:04.03.2021.

10. Fox, M. Holiday etiquette: The top 10 rules for gift-giving this holiday season. CNBC. Dec. 5. 2019. URL: https://www.cnbc.com/2019/12/04/holiday-etiquette-for-gitt-givingthis-season.html. Date: 03.03.2021.

11. Gottsman, D. (2017) Modem Etiquette for a Better Life: Master All Social and Business Exchanges Paperback-Illustrated. Page StreetPublishing.-192p.

12. Murray, M. (1999) Put Your Best Foot Fonward. Book 6. Intl Education Systems. - 480 $\mathrm{p}$.

13. Murtaugh, T. 14 Classic New Year's Eve Traditions We Leamed from Our Grandparents. CountryLiving. NOV 6, 2020. URL: hitps://www.countryliving.com/life/g5075/new-years-eve-traditions/. Date: 03.03.2021.

14. Proper American Etiquette in the United States. Englishclass101.com January 6, 2020. URL: https:/www.englishclass101.com/blog/2020/01/06/english-etiquette/. Date: 03.03.2021.

15. Schweitzer, Sh. 7 Dining Etiquette Tips to Master a Business Meal. URL: hitps://www.protocolww.com/7-dining-etiquette-tips-to-master-a-business-meal. Date: 04.03.2021.

16. Schweitzer, Sh. Access to Culture. URL: https://www.protocolww.com/. Date: 03.03.2021.

17. Schweitzer, Sh. Your First Office Holiday Party: A Survival Guide. URL: hitps://www.protocolww.com/office-holiday-party-a-survival-guide/.Date:04.03.2021.

18. Tsai,B. BeyondEtiquette.URL:https//www.beyondetiquette.col.Date:04.03.2021.

19. United States (American) dining etiquette. Etiquette scholar. URL: hitps://www.etiquettescholar.com/dining etiquette/table-

etiquette/na_table_manners/american.html. Date:04.03.2021.

20. Wexler, S. How to Swing Like A Southem Belle - Even If Youre Frozen in The North. URL: hitp://www.suzannewexler.com/.Date:03.03.2021.

21. Youst, J. PAlive! Holiday Work Party Etiquette. URL: hitp://www.jacquelynyoust.com/press-room-jacquelyn-youst. Date:03.03.2021.

(C) ДжунусбековаЖ.С.,2021 г. 